\title{
A Group Investigation Learning System for Open Educational Resources to Enhance Student Teachers' Digital Literacy and Awareness in Information Ethics
}

\author{
S. Jongsermtrakoon and J. Nasongkhla
}

\begin{abstract}
Open Educational Resources (OER) are contents, courses and digital educational materials under open licenses, which has increased opportunities for people who are in needs to reuse learning materials. Universal resources can made a negative effect of unaware usage without truly comprehend ethics by users who don't precautious on the use of those digital media via appropriated strategies. Accordingly, OER sites should cover investigative learning system that help to evaluate resources for proper use. The system should be focused on searching and evaluation a large amount of resources to enhance digital literacy, which means ability to use digital materials included skills of define, access, evaluate, manage, integrate, create and communicate. Thus, this research is aimed to develop the system using group investigation technique in utilizing OER for student teachers' digital literacy and awareness of information ethics. The study is also discussed about behavior of reuse, redistribute, revise or remix of OER.
\end{abstract}

Index Terms-Group investigation, open educational resources, OER, digital literacy, information ethics.

\section{INTRODUCTION}

More than a decade, Open Educational Resources have been widely used around the world. In Thailand, few educators or researchers, who have consciously attended educational movement, perceive OER as a tool for an academic and collaboration activities.

However, a proper use of OER either in general or in school still not clearly found in Thai context. Researcher then conducted a survey on Thai open educational resources websites and found that almost of Educational websites displayed open creative commons license (CC) are from government, non-profit organization, and private sector solicited with government as shown in Table I.

It was not only difficult to find open educational resources in Thai websites, but evidences of Thai teachers and learners' demand of OER were also hardly found. On the other hands, Thai people normally surfed on the Internet and collected what they wanted by downloading them in the moment they found and used with careless of owner permission. It could be assumed that Thai people must have a huge gap of understanding about the use of OER products under copyright with open license. Recently, countries initiated OER have moved from OER production and sharing to its implementation. Masterman and others [1] reported aspect of the study about learning design practice in approaches that

Manuscript received March 2, 2014; revised May 13, 2014.

The authors are with Chulalongkorn University, Bangkok 10330 Thailand (e-mail: sukandajong@gmail.com, jaitipn@gmail.com). supported sharing, collaboration and accessing to open knowledge and resources. The researchers gathered data from workshop associated with OER use by giving participants tasks to search and evaluate OER for incorporating participants' learning design. They found that pedagogic factors in selection and evaluation OER were provenance, goodness of fit to the lecturer's purpose, pedagogic intent embedded in a resource and granularity. To encourage teachers to use available open resources on the Internet with respect to intellectual property rights, a development of OER learning space could play a significant role in preparing and training users to use open resources in a decent manner.

\section{A. Research Questions}

The researcher aimed to research and develop a learning system for an open educational resources (OER) implementation with two research questions as follows:

1) Whether or not the group investigation learning system for OER increase digital literacy or information ethic of student teachers?

2) What are the OER levels of usage in terms of four R's framework?

\section{B. Target Population}

Research found Thai teachers commented that they had not much enough skill to prepare digital learning materials, caused by a lacking of instructional media training when they were student teachers [2]. Hence, a proper training strategy for teachers to develop learning materials effectively by using open educational resources should be a solution. Therefore, the target population was student teachers who had previous experiences in both lesson plans and learning materials development. Sampling group was purposively selected from from Faculty of Education at Chulalongkorn University in Bangkok. These students were enrolled in Methodology of Teaching, which was designed to give experience in teaching before getting to their internship. Nineteen student teachers enrolled to the course and all was selected to be a sampling group.

\section{RESEARCH PROCEDURE}

The research methodology consisted of four phases that were:

\section{A. Phase 1: Study of Research Framework}

The research procedure started from the study of theories and related research to find the idea of the learning system development, which assigned workload to design lesson 
plans and learning materials for publication as open educational resources. The researcher studied group investigation learning principle or GI, which students participated in a group to take an active part in planning what they want to find the answer together according to their interested topic, and all members cooperated to investigate, synthesize and summarize their works for presenting the results to class [3]-[5]. Group process allows students to discuss on their topic to solve problems [3], [6]. As mentioned above, group members would investigate the subtopic each one of a group topic on open educational resources and joined the finding on group discussion.
Otherwise, they need to think about the use of open educational resources accurately and appropriately with regard to respect for the rights of the work pieces' owner. Thus, the concept of digital literacy, which talked about how to define, access, evaluate, manage, integrate, create and communicate digital resources on the internet [7]-[9], and the concept of the awareness in information ethics, which described ethical use of others with regard to information privacy, accuracy, property and accessibility [10], [11], were the must have skills in the use of OER.

TABLE I: THAI OER'S WEBSITES SURVEY IN 2013

\begin{tabular}{|c|c|c|c|c|}
\hline Address & Details & Open license & Type of service & Response by \\
\hline http://pim.in.th & Thai cuisine recipes & $\begin{array}{l}\text { CC-BY-NC-ND } 3.0 \\
\text { Thailand }\end{array}$ & Open resources & $\begin{array}{l}\text { Pim/Site's owner } \\
\text { (Google adsense appeared on site) }\end{array}$ \\
\hline http://edltv.thai.net & $\begin{array}{l}\text { E-learning contents for } \\
\text { distance learning }\end{array}$ & $\begin{array}{l}\text { CC-BY-NC-ND } 3.0 \\
\text { Thailand }\end{array}$ & Open resources & $\begin{array}{l}\text { Distance Learning Foundation } \\
\text { (Non-profit organization) }\end{array}$ \\
\hline http://www.thaicyberu.go.th & $\begin{array}{l}\text { E-learning contents and } \\
\text { open courseware }\end{array}$ & None & $\begin{array}{l}\text { Open resources } \\
\text { Learning space }\end{array}$ & $\begin{array}{l}\text { Thailand Cyber University } \\
\text { (Under the Ministry of Education) }\end{array}$ \\
\hline $\begin{array}{l}\text { http://www.trueplookpanya.co } \\
\text { m }\end{array}$ & E-learning contents & $\begin{array}{l}\text { CC-BY-NC-ND } 3.0 \\
\text { Thailand }\end{array}$ & Open resources & $\begin{array}{l}\text { True Corporation Public Company } \\
\text { Limited } \\
\text { (Not for commercial) }\end{array}$ \\
\hline http://south.psu.ac.th & Open courseware for & None & Learning space & Songklanakarin University \\
\hline http://www.caistudio.info & $\begin{array}{l}\text { E-learning contents in } \\
\text { form of CAI and open } \\
\text { courseware }\end{array}$ & None & $\begin{array}{l}\text { Open resources } \\
\text { Learning space }\end{array}$ & $\begin{array}{l}\text { Jirapong Khampuang } \\
\text { /Site's owner } \\
\text { (Not for commercial) }\end{array}$ \\
\hline $\begin{array}{l}\text { http://learnsquare.com/learnsq } \\
\text { uare }\end{array}$ & $\begin{array}{l}\text { Open courseware for } \\
\text { computer and } \\
\text { technology }\end{array}$ & $\begin{array}{l}\text { GNU General public } \\
\text { license V } 2.0\end{array}$ & Learning space & $\begin{array}{l}\text { Thailand National Electronics and } \\
\text { Computer Technology Center }\end{array}$ \\
\hline http://fieldtrip.ipst.ac.th & Virtual fieldtrip & $\begin{array}{l}\text { CC-BY-NC-ND } 3.0 \\
\text { Thailand }\end{array}$ & $\begin{array}{l}\text { Open resources } \\
\text { Learning space }\end{array}$ & $\begin{array}{l}\text { Thailand National Science and } \\
\text { Technology Development Agency }\end{array}$ \\
\hline http://malayu.nectec.or.th & $\begin{array}{l}\text { Malayu language } \\
\text { learning courseware }\end{array}$ & None & $\begin{array}{l}\text { Open resources } \\
\text { Learning space }\end{array}$ & $\begin{array}{l}\text { Thailand National Electronics and } \\
\text { Computer Technology Center }\end{array}$ \\
\hline http://karen.nectec.or.th & $\begin{array}{l}\text { Phagagayor language } \\
\text { learning courseware }\end{array}$ & None & $\begin{array}{l}\text { Open resources } \\
\text { Learning space }\end{array}$ & $\begin{array}{l}\text { Thailand National Electronics and } \\
\text { Computer Technology Center }\end{array}$ \\
\hline $\begin{array}{l}\text { http://en.wikipedia.org/wiki/T } \\
\text { hai_cuisine }\end{array}$ & Thai cuisine & CC-BY-SA 3.0 & Open resources & Wikipedia \\
\hline
\end{tabular}

\section{B. Phase 2: Development of the Learning System}

The second phase used the above principles as research framework to develop learning system, then the researcher interviewed for further advice with five experts, who were professional specialists in educational technology and communication, learning media development and open educational resources. After improving the learning system upon the advice, we designed and developed learning system active site as an important tool in this research. Afterwards, evaluation of the learning system and its active site using five level Likert-scales was committed by other group of experts, which consisted of expertise in line with the first groups in the same numbers. Results of the evaluation showed experts' opinion average points were very good in almost criteria and good for the rest. That meant it was appropriate to bring the learning system and its active site to implement with samples. The certified learning system was shown in Fig. 1 and its active site was shown in Fig. 2.

\section{Phase 3: Implementation of the Learning System}

The third phase was an implementing for the learning system, which the main instruments for collecting data were the digital literacy assessment, the awareness in information ethics assessment and the use of OER behavior observation. First two assessments were certified by three university lecturers who experts in Educational Technology and Communication, Literacy and ICT skills. In term of the methodology, we collected data from the pre-test of both outcome skills after the orientation. When the existing results of the investigation presented as open educational resources, they were given to take post-test for evaluation their digital literacy and awareness in information ethics skills. As we mentioned before, the use of OER behavior have been observed as an information gathering for the study of how student teachers used existing open educational resources for repurposing and sharing back in the term of OER with Creative Commons license. We observed the behavior of OER use from traces of learning activities on the active site system, which was a learning management system named Moodle, and use the certified form from three OER experts to observe them.

\section{Phase 4: Approving the Learning System}

After five weeks implementation with 19 student teachers who participated as research subjects, the researcher brought the complete learning system with its results for the instructional system verification by five experts. 


\section{INPUT}

1. Learning Objective : Learners achieve digital literacy and awareness in information ethics.

2. Instructor: Instructor plays an important role as facilitator.

3. Learner : Student teachers who had previous experiences in both lesson plans and learning materials design and development

4. Learning environment : Learning system active site and workload

\begin{tabular}{|c|}
\hline PROCESS \\
\hline $\begin{array}{l}\text { Learning procedure } \\
\text { 1. Learning system orientation } \\
\text { 2. Group investigation learning process (identify topic, plan } \\
\text { to investigate, carry out the investigation, prepare final } \\
\text { product, present and evaluate) }\end{array}$ \\
\hline $\begin{array}{l}\text { Learning conditions } \\
\text { 1. Online learning } \\
\text { 2. Investigation (define, access, evaluate, manage) on OER } \\
\text { 3. Publication OER (Integrate, create, communicate) by } \\
\text { using Creative Commons }\end{array}$ \\
\hline
\end{tabular}

OUTPUT

1. Digital literacy

2. Awareness of information ethics

3. Behavior of OER use (Reuse, Redistribute, Revise and Remix)

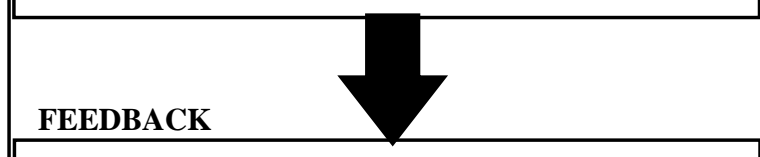

Problems occur during the execution will be fed back to the system development.

Fig. 1. A group investigation learning system on open educational resources for digital literacy and awareness in information ethics of student teachers, which has been certified from experts.

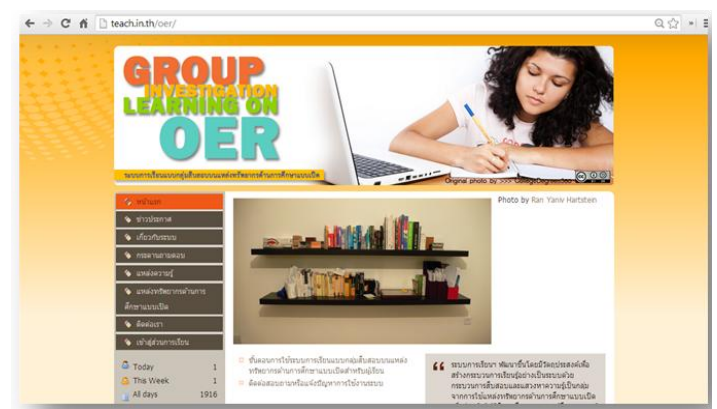

Fig. 2. An active site for a group investigation learning system on open educational resources for digital literacy and awareness in information ethics of student teachers.

\section{RESULTS AND DISCUSSION}

Finding 1: Did a group investigation learning system on OER impact digital literacy or information ethics?

\section{A. Results}

All numerical data collected were analyzed using SPSS and the analyses sought to study scales between pre-test and post-test of digital literacy and awareness of information ethics. This research used one group pre-test post-test design. The results of statistical analyses including mean scores, standard deviation and the paired sample $t$-test for each pair of output skills presented in Table II.

TABLE II: STATISTICAL ANALYSES FOR PRE-TEST AND POST-TEST SCORES OF DIGITAL LITERACY AND AWARENESS IN INFORMATION ETHICS $(N=19)$

\begin{tabular}{lccc}
\hline \multicolumn{1}{c}{ Test result } & $\chi$ & S.D. & Sig. \\
\hline $\begin{array}{l}\text { Digital literacy } \\
\text { Pre-test }\end{array}$ & 13.00 & 2.85 & \\
Post-test & 18.53 & 6.44 & $* .005$ \\
Awareness in information ethics & & & \\
Pre-test & 19.84 & 4.88 & $* .000$ \\
Post-test & 25.68 & 4.36 & \\
\hline \hline
\end{tabular}

*Significant .05(95\% confidence interval of the difference)

Table II indicated pre-test mean scores of digital literacy, which full marks were 24 points and the sample got a mean score equal 13.00. In the line of same full scores, the sample got a mean post-test score equal 18.53 points. Then we used the paired sample $t$-test to analyze and found that the significant value was 0.005 . It appeared that pre-test and post-test scores of digital literacy was different with significant at the 0.05 level. From the study, it can showed that the digital literacy post-test scores were significantly higher than the pre-test scores at the 0.05 level. In addition, the awareness in information ethics pre-test mean scores were 19.84 and its post-test mean scores were 25.68. The paired sample $t$-test analysis has got significant value of awareness in information ethics pre-test post-test equal 0.000 . The result showed that its value was different between pre-test post-test with significant at the 0.05 level. It reported that the awareness in information ethics post-test scores were significantly higher than the pre-test scores at the 0.05 level.

According to the study, we found answers for the Finding 1 that the group investigation learning system on open educational resources did affection on learners' digital literacy and awareness in information ethics skills. An observation from traces on active site showed that group discussion helped learners to think critically on how to select and evaluate OER for repurposing focus on the subject of intellectual property rights. That can explained why group investigated process effected to the higher post-test scores of digital literacy and information ethics skills.

\section{B. Discussion}

\section{1) Digital literacy}

Supported evidences for this finding were the designed learning activities for the process of the learning system in purpose to actuate students to practice skills of digital literacy step by step of a group investigation process included define, access, evaluate, manage, integrate, create and communicate which described as follows:

a) Define

Step 1 Identifying the topic to be investigated and step 2 Planning the investigation in groups were the activities which commanded students to discuss in groups to define their goals and the details of needed resources.

b) Access

In step of the planning, students had to plan to access to the 
educational resources with the appropriate approach that could carry all resources to use of their purposes.

c) Evaluate

Step 3 Carrying out the investigation was gathering information and media stage from a variety of sources. In this step, students had to make their own decision to select and evaluate information and media before took it to discuss and re-evaluate in groups.

\section{d) Manage}

In the carrying out stage, students needed to manage all selected data and media by organizing in related categories to prepare resources for learning media development.

\section{e) Integrate}

Additionally in step 3, students would participate in groups to design the target learning materials by integrating the variety of data and media collections.

\section{f) Create}

Among the integrating, all members asked to join the creation of the masterpiece work in groups.

\section{g) Communicate}

Step 4 Preparing a final report and step 5 Presenting the final report were to prepare to publicize students' answers of investigation in form of learning materials under Creative Commons licenses.

\section{2) Awareness in information ethics}

According to the above, the group investigation learning process could encourage students to improve digital literacy skills. In the other hands, an important condition of the learning process forced students to use materials from OER or any free resources to develop and share as OER. This condition reminded students to think of awareness in information ethics, included information privacy, information accuracy, information property and data accessibility which described as follows:

\section{a) Information privacy}

Students must be considered about information privacy while doing learning activities under the condition to produce their works as OER which allowed others to reuse them. Thus, their works must not violated the privacy or effect other goods.

\section{b) Information accuracy}

Sharing their works as OER asked to announce attribution in every CC licenses. Users might be reused or redistributed the creation in any purpose along with owners' name that would remind students to check for all the accuracy of the works before public.

\section{c) Information property}

Information property was the most important issue of ethics under CC licenses, because CC licenses used to allow a free of use permission on owner works. In the learning system, students must be reminded to select materials without infringing the intellectual to procude the new creation for sharing on the internet as open educational resources.

\section{d) Data accessibility}

Groups must not only planed and defined to access to the suitable educational resources, but they must also took into consideration about user authority. They must not used other account or smuggle into impervious resources.

Finding 2: What was the level of openness in the use of OER in this research?

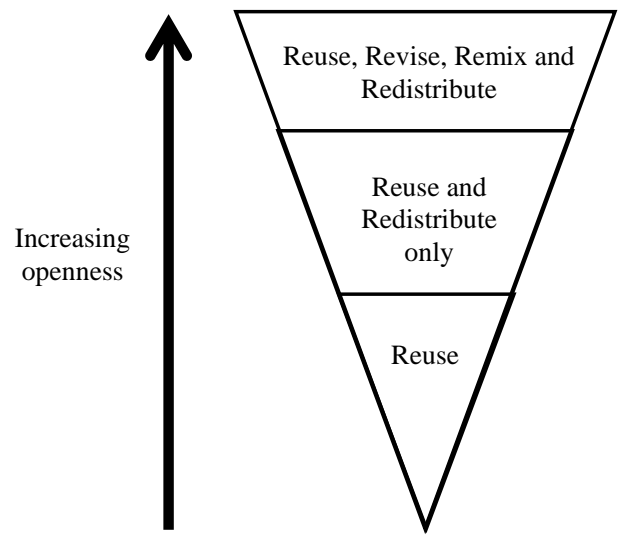

Fig. 3. The increasing openness of the four R's [12].

TABLE III: CREATIVE COMMONS LICENSES [13]

\begin{tabular}{cl}
\hline \hline Symbols & \multicolumn{1}{c}{ License description } \\
\hline Attribution / CC BY \\
This license allows for redistribution even build \\
on your work or for commercial purpose as long \\
as user credit for your original creation.
\end{tabular}

Attribution-ShareAlike / CC BY-SA

This license allows for redistribution even build on your work or for commercial purpose as long as user credit for your original creation under the identical terms to license their new creations.

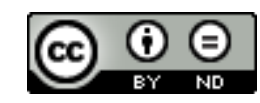

Attribution-NoDerivs / CC BY-ND

This license allows for redistribution even for commercial purpose as long as user pass along without change in whole and credit for your original creation.

Attribution-NonCommercial / CC BY-NC

This license allows for redistribution even build on your work for non-commercial purpose only. User must credit for your original creation but they don't have to license their new works on the same terms.

Attribution-NonCommercial-ShareAlike / CC $B Y-N C-S A$

This license allows for redistribution even build on your work for non-commercial purpose only. User must credit for your original creation under the identical terms to license their new creations.

Attribution-NonCommercial-NoDerivs / CC $B Y-N C-N D$

This license allows to download and share your works without change and for non-commercially only as long as user credit your original creation.

Hilton III and Wiley [12] presented four R's of openness in terms of reuse freely available resources in different contexts. These four R's represents an increasing level of openness. They are as follows:

Reuse - This is a basic level of openness to use other creation for own purposes.

Redistribute - The second level of openness that people can share works with others.

Revise - This level, people can change or modify a work and share with others.

Remix - The top level, people can combine two or more resources for new creations.

As mentioned above, the increasing openness of the four 
R's shown in Fig. 1. It means if we want to create or repurpose OER in high level of openness, we should declare the creation with freely modified licenses. The open license created by Creative Commons organization [13] is well-known using throughout the world with six licenses. All Creative Commons licenses have one main condition to credit owner original creation and others upon the use contexts. Creative Commons symbols and license description were shown in Table III.

\section{Result}

From the observation focus on the use of OER on the learning system active site, we found that all sample group use the Attribution and Not for Commercial Creative Commons license (CC BY-NC) for lesson plans and learning materials publication trough Google sites. Although the student teachers in an experiment were chosen the same licenses to share their works as open educational resources, but the level of openness were not the same results as shown in Table IV.

TABLE IV: LEVEL OF OPENNESS IN THE USE OF OER OF A GROUP INVESTIGATION LEARNING SYSTEM ON OER OF STUDENT TEACHERS

\begin{tabular}{ccc}
\hline Group & $\begin{array}{c}\text { Level of } \\
\text { openness }\end{array}$ & Creative Commons license use \\
\hline Group 1 & $\begin{array}{c}\text { Redistribute } \\
\text { Remix }\end{array}$ & $\begin{array}{c}\text { Attribution-NonCommercial / } \\
\text { CC BY-NC }\end{array}$ \\
Group 2 & None & Attribution-NonCommercial / \\
& CC BY-NC \\
Group 3 & Redistribute & Attribution-NonCommercial / \\
& Remix & CC BY-NC \\
& & Attribution-NonCommercial-Share \\
& & Alike / CC BY-NC-SA \\
Group 4 & Redistribute & Attribution-NonCommercial / \\
& Remix & CC BY-NC \\
Group 5 & Remix & Attribution-NonCommercial / \\
& & CC BY-NC \\
Group 6 & None & Attribution-NonCommercial / \\
& (New creation) & CC BY-NC \\
\hline \hline
\end{tabular}

\section{Dicussion}

According to Table IV, the lowest level of openness was Redistribute. The sample selected the existing open educational resources on the internet and redistributed along with their lesson plans. In additional, it was found that majority use of OER for student teachers was Remix. It was probably because of the design of a specific lesson plans were hardly consistent fit to be found and used any OER by Redistribute or Revise. Furthermore, the observation from the traces on learning system active site showed that learners search and found open educational resources both with Creative Commons licenses or others and without any open licenses, which were appeared only free available to use. That was might be an important reason to make decision to use Attribution-Not Commercial licenses (CC BY-NC) in every groups, because of some original works were not identified themselves as OER in terms of freely to build upon their works and share as new creation with copyrights. Moreover, the result from Table IV showed that 2 groups of them did not reuse, redistribute, revise or remix OER. They only designed and developed new creation and published as open educational resources as free learning materials without using any media from others. It can referred from traces on group discussion board on the learning system active site that their targets did not fit with any OER they found.

In addition of those findings, the five experts in Educational Technology thinking fields approved and confirmed that the learning system was efficient and suitable for student teachers.

\section{CONCLUSION}

This study was research and development focus on design and develop a group investigation learning system for digital literacy and awareness in information ethics of student teachers, who we should prepare prior to a professional in-service teacher. Main ideas for learning system design were a group investigation, which aimed to let student teachers brainstormed and discussed their opinions to define, access, evaluate, manage, integrate, create and communicate for the use of OER. During the group learning activities, they would achieve digital literacy in the end of the process and the task to share their works as OER was an important condition that made them carefully used OER in matters of intellectual property rights. The results of implementing showed that the group investigation learning system on open educational resources did affection on learners' digital literacy and awareness in information ethics skills with higher post-test scores at 0.05 significant level. Moreover, it was found that the level of openness for the use of OER appeared in Redistribute as basic openness, but mostly found in Remix. The probability reason was specific design in their lesson plans made difficulty finding the accordance learning materials with the contents.

\section{FURTHER STUDY}

Despite the preliminary nature of our findings, we knew that real life environment to work in schools was different from the context of our research. Then, we should expand the study to try out with in-service teachers under the same workload to design and develop lesson plans and learning materials using an online group investigation on open educational resources. The expand study results will answer this research question more completely.

\section{REFERENCES}

[1] L. Masterman et al., "The impact of OER on teaching and learning in UK universities: implications for learning design," presented at International LAMS and Learning Design Conference, 2011.

[2] K. Pimrot, "A study of state and problems concerning the use of information and communication technology in science instruction of teachers in secondary schools participating in SchoolNet Thailand," Project under the Department of General Education, educational region ten, 2003, (Thai).

[3] T. Khammanee, Teaching Pedagog: Knowledge for Efficiency Learning Management, Bangkok: Chulalongkorn University Printing, 2012.

[4] P. Pornpeerachon, Learning Methodology Management, Songkhla: Thame Songkhla Printing, 2007.

[5] S. Sharan, "Group investigation expands cooperative learning," Educational leadership, pp. 17-21, December, 1989 - January, 1990.

[6] P. Satthayatham, Efficiency Teaching Techniques for All Level Teachers, Bangkok: Ruenkeaw Printing, 1981.

[7] Martin and Madigan, Digital Literacies for learning, London: Facet publishing, 2006.

[8] KEMPSTER. (2008). California ICT digital literacy assessments and $\begin{array}{lll}\text { curriculum } & \text { framework. } & \text { Anline]. }\end{array}$ 
http://www.ictliteracy.info/rf.pdf/California\%20ICT\%20Assessments $\% 20$ and\%20Curriculum\%20Framework.pdf

[9] Education Testing Service. (2007). Digital Transformation A Framework for ICT Literacy. [Online]. Available: http://www.ets.org/Media/Tests/Information_and_Communication_Te chnology_Literacy/ictreport.pdf

[10] B. Chunsawang, "Information and literacy," Literacy skills, Bangkok: Srinakharinwirot University, 2005, pp. 1-5.

[11] T. Natewong, Information Technology, Suan Dusit Rajabhat University, pp. 159-178.

[12] J. Hilton III and D. Wiley, "The creation and use of open educational resources in Christian higher education," Christian Higher Education, vol. 9, no. 1, pp. 49-59, December 2009.

[13] Creative Commons. (2012). Creative commons. [Online]. Available: http://creativecommons.org

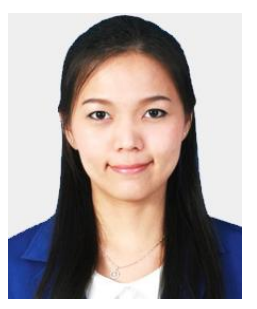

Sukanda Jongsermtrakoon was born in Surin, Thailand on December 28, 1984. She is listed in master of educational technology and communication at Chulalongkorn University, Bangkok, Thailand, 2012 to present.

She was a teaching and research assistant in the division of educational technology and communication at Faculty of Education, Chulalongkorn University, 2012-2014. Background of her profession was an outstanding computer teacher, awarded by the Bangkok Metropolitant Office in the year of 2012, and Bangkok Christian College was her affiliation during 2007-2012. Her inspired work is in Open Educational Resources and MOOCs; then came to her initial document research on "Tendency of OER Use: Open Education Resources in ASEAN Community" in national e-learning conference 2012 provided by Thailand Cyber University.

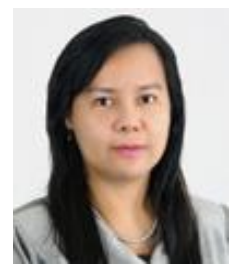

Jaitip Nasongkhla is a Ph.D. She has been with Chulalongkorn University, Bangkok, Thailand since 1998. She is currently the head of the master program in educational technology and communication at Faculty of Education.

Her publications are in the area of e-learning, Table technology for teachers professional development and pre-service teacher Education. Her contributions have also covered the area of Educational Policies and mainly on the open conten for Life Long learning Currenlty as OER in liflong learning, tablet technology for a classroom innovative action research (CIAR), collective learning through crit. Her international research networks in Asia and Europe have currently been committed to the area of Massive Open Online Courseware. 